DOI: $10.24193 /$ tras.SI2020.7

Published First Online: 11/23/2020

\section{ABOUT THE FAIR BALANCE OF COMPETING RIGHTS IN THE CONTEXT OF THE COVID-19 PANDEMIC}

\author{
Georgeta-Bianca SPÎRCHEZ \\ Nicolae BÂRSAN-PIPU
}

\section{Georgeta Bianca SPÎRCHEZ}

Assistant professor, Department of Law, Faculty of Law, Transilvania University of Brașov, Brașov, Romania

Tel.: 0040-724-517.037

E-mail: georgeta-bianca.spirchez@unitbv.ro

\section{Nicolae BÂRSAN-PIPU}

Associate professor, Department of Management and Economic Informatics, Faculty of Economic Sciences and Business Administration, Transilvania University of Brașov, Brașov, Romania E-mail: nicolae.barsan@unitbv.ro (1) we found it appropriate to make general considerations related to governmental measures for public health and safety in the introductory part, we continued with (2) the presentation of the proportionality standard, as a jurisprudential model used both at national and international level, in order to develop (3) proportionality in a narrow sense afterwards, using the formula of professor Robert Alexy, which we consider representative for the structure of balancing competing rights, using a quantifiable model, in which respect we have exemplified the applicability of this formula (4). Finally, we concluded that the principle of proportionality can be a convincing structural approach in the legal reasoning designated to promote the balance of principles (6), although we acknowledge some of the limitations of the proposed method, which we consider that can be overcome (5).

Keywords: proportionality principle, law of balancing, weight formula, competing rights, pandemic, Sars-Cov-2. 


\section{General considerations regarding the restrictive measures adopted in the context of the COVID-19 pandemic}

It is well known that the current pandemic context has determined all countries in the world to take extraordinary measures that have had significant consequences in all areas of social, economic and political life, but above all they have had an unprecedented impact on a wide range of fundamental human rights.

If we refer to the situation in Romania, during the state of emergency, by the Decree of the President of Romania no. 195 from March 16, 2020, published in the Official Gazette of Romania, Part I no. 212 from March 16, 2020, article 2 indicates the limitation of enforcement of the following rights: the right to free movement, the right to intimate, family and private life, the inviolability of the home, the right to education, the freedom of assembly, the right of private property, the right to organize a strike, and economic freedom.

Moreover, Romania, as well as Latvia and Estonia, have used the possibility recognized by article 15 of the European Convention on Human Rights to derogate from this convention during the state of emergency, which in the opinion of the specialized doctrine (Mazilu-Babel, 2020) will generate, from the European Court, an even more detailed analysis regarding the proportionality of the measures thus adopted, in order to remove any risk of abusive claim of such a derogation.

At EU level, an analysis assessing the implications of the measures taken during the pandemic (European Union, Agency for Fundamental Rights, 2020) notes the impact on the following rights guaranteed by the Charter of Fundamental Rights of the European Union: the right to liberty and security, respect for private and family life, freedom of thought, conscience and religion, freedom of assembly and association, freedom of the arts and sciences.

As established in the case law developed in the system of human rights protection, health policy is, in principle, at the discretion of national authorities (European Court of Human Rights, 2015), which means that they enjoy a certain autonomy in the application of the Convention, recognizing that they are the most able to assess the necessity and adequacy of restrictions (Spielmann, 2012, p. 382). However, their decision remains subject to judicial review and to the European Court of Human Rights review, which has the prerogative to verify that the margin of appreciation granted to national authorities does not exceed the limitations imposed by a democratic society (Bârsan, 2003), and thus be within the area of excess power.

Therefore, in this context of analysis, it is natural to refer to the main standard of analysis available to the judicial system, in order to examine the extent to which the authorities have managed to strike a fair balance between the need to prevent the spread of the Sars-Cov-2 virus, and therefore to ensure public health and safety, respectively the other fundamental human rights.

As we have shown on other occasions (Spîrchez and Șaramet, 2018, p. 79), when we analyzed whether or not the discretionary limits of the authorities were exceeded, the useful tool to use is, without doubt, the proportionality principle. 


\section{The proportionality principle, 'the solution of optimizing two competing constitutional values'}

The title of this section was inspired by the assessments of the research literature (Pivniceru and Benke, 2015, p. 58) according to which proportionality is seen both as an interpretive method, but also as a general principle of law, representing 'the solution of optimization of two conflicting/ competing constitutional values', which must be limited in order for each of them to reach its finality/ optimal effect. What is relevant is also the fact that the doctrine (Papuc, 2019, p. 279) holds that 'the proportionality test is a more detailed exercise and preferable to a categorical denial of the protection of a right to the interpretive stage'.

Of German origin (Poole, 2010, pp. 1-2), the proportionality principle has gained its well-deserved place among the fundamental principles of any state that wants to be a state governed by the rule of law, being recognized as such at the level of international organizations, worldwide or regionally.

The doctrine (Klatt, 2019) considers that the proportionality is 'the dominant technique of rights adjudication in the world. It is not just a test or a method among many others. Rather, proportionality is the main means that allows to structure justificatory processes in rights reasoning to the utmost possible degree of rationality'.

Thus, this principle is regulated at the level of the European Union by article 5 of the Treaty on European Union, which provides in paragraph 4 as follows: 'Under the principle of proportionality, the content and form of Union action shall not exceed what is necessary to achieve the objectives of the Treaties. The institutions of the Union shall apply the proportionality principle as laid down in the Protocol on the application of the principles of subsidiarity and proportionality'. At the same time, in accordance with article 52 (1) of the Charter of Fundamental Rights of the European Union, 'any limitation on the exercise of the rights and freedoms recognized by this Charter must be provided for by law and respect the essence of those rights and freedoms. Subject to the principle of proportionality, limitations may be made only where they are necessary and genuinely meet objectives of general interest recognized by the Union or the need to protect the rights and freedoms of others'.

The explanations of the Charter of Fundamental Rights of the European Union (European Court of Human Rights, 2007) state that, according to a settled case-law, one may impose limitations on the enforcement of fundamental rights, provided that such limitations actually meet objectives of general interest and do not constitute, in relation to the aim pursued, a disproportionate and intolerable intervention which would infringe the very substance of those rights.

In the system of the European Convention on Human Rights, this principle resides in the values proclaimed by the Convention, namely democracy and the rule of law (Papuc, 2019, p. 275).

The proportionality principle is also settled at the constitutional level, and in this respect, we shall refer to the Romanian Constitution, which in article 53 provides that 
the limitation of the enforcement of rights and freedoms is done only by means of law and in compliance with the conditions set out in the same constitutional text.

Moreover, when invested with solving an exception of unconstitutionality, claimed by the Ombudsman, in the context of the measures adopted during the Covid-19 pandemic, the Romanian Constitutional Court recalled, by means of an appeal against the facts established in its case law (The Decision of the Constitutional Court of Romania no. 458 from June 25, 2020 published in the Official Gazette of Romania, Part I no. 581 from July 2, 2020, item 33), that the limitation of the enforcement of a fundamental right or freedom may be regulated, in compliance with the provisions of article 53 of the Fundamental Law, if: it is provided by law; it is necessary to limit the right or freedom; the restriction is limited to the reasons expressly provided by the constitutional text, namely to: the defense of national security, order, health or public morality, the rights and freedoms of citizens; the conduct of criminal investigation; the prevention of the consequences of a natural calamity, of a disaster or of a particularly serious event; the measure is necessary in a democratic society; the limitation is proportionate to the situation which determined it; it is applied in a non-discriminatory manner; it does not affect the existence of a right or freedom.

The doctrine (Papuc, 2019, p. 280) shows that the proportionality test is preceded by the legality test which, in essence, verifies the existence of a legal basis in the national system for the establishment of the intrusive measure, the accessibility of that legal provision, the sufficiently precise nature of the rule enabling the person to reasonably foresee the consequences of his/her action, and the existence of adequate safeguards in the law against arbitrary interference with the material rights in question.

After the 'passing' of the legality test, the legitimate aim pursued must be established and by virtue of which this interference of a right guaranteed by law is accepted (Papuc, 2019, p. 281), which in the pandemic context subject to examination should not be difficult to achieve - as we are talking about public health and safety.

In the documentation of the proportionality principle, the contribution of professor Robert Alexy, in whose opinion the proportionality principle consists of three sub-principles, namely that of adequacy, necessity and proportionality in a narrow sense is significant (Alexy, 2014, p. 52).

Professor Alexy believes that the principles of adequacy and necessity refer to the optimization in relation to the factual possibilities, while the proportionality principle in a narrow sense refers to the optimization in relation to the legal possibilities. The mentioned author (Alexy, 2014, p. 54) considers that optimization in relation to factual possibilities consists in avoiding avoidable costs, although these are inevitable when we talk about competing rights, as a result of which a balancing, which is the essence of the third sub-principle, is necessary. In fact, professor Alexy recalls the Law of Balancing according to which 'the greater the degree of dissatisfaction of one principle is, the greater the importance of satisfying the other principle must be'.

In order to understand the first two sub-principles it was also shown (Pivniceru and Benke, 2015, p. 56) that the one regarding the adequacy 'excludes the adoption 
of regulations that obstruct the achievement of at least one principle and that do not promote the purpose in consideration of which they have been adopted', while the sub-principle of necessity 'implies that, of two equally appropriate regulations that promote a certain right/principle, the one that implies less interference with another right/ principle will be chosen'.

The third sub-principle, which is the result of professor Alexy's elaboration of the so-called Law of Balancing, will be presented next.

\section{Methodology for the sub-principle of proportionality in the narrow sense. Alexy's Weighting Formula}

The Law of Balancing was expressed by Alexy defining the so-called Weight Formula (Alexy, 2014, p. 55), as:

$$
W_{i j}=\frac{I_{i} \cdot W_{i} \cdot R_{i}}{I_{j} \cdot W_{j} \cdot R_{j}}
$$

The above formula quantifies the weight $W_{i j}$ of a principle $P_{i}$ against an opposite principle $P_{j}$, as the ratio of the product of three coefficients, on each side of balancing equation, where first $I_{i}$ is the intensity of the interference with $P_{i}, W_{i}$ is the weight of $P_{i}$, and $R_{i}$ the degree of reliability of $P_{i}$, and, second, the product of the corresponding values with respect to the principle $P_{j}$.

To evaluate the three coefficients for each principle, Alexy first proposed a qualitative approach, with a triadic scale, having the values light $(\mathrm{l})$, moderate $(\mathrm{m})$, and serious (s). For the quantitative assessment of the coefficients, Alexy has recommended a numerical sequence with the values $2^{0}, 2^{1}$, and $2^{2}$, namely 1,2 or 4 . This model has the advantage of taking account of the fact that the power of principles increases exponentially with an increasing intensity of interference.

In order to determine the value of the reliability, Alexy used a categorical scale with the stages reliable or certain (r), plausible (p), and not evidently false (e), to which he assigned a decreasing numerical scale, when uncertainty increases, respectively the exponentially series $2^{0}, 2^{-1}$, and $2^{-2}$, namely $1,1 / 2$ and $1 / 4$.

Mixing the categorical triadic scale with the corresponding values of the three coefficients, and applying the Weight Formula, we obtain the following decision rules for balancing the principles $P_{i}$ and $P_{j}$ (Klatt and Mesister, 2012, p. 12): if $W_{i j}$ is greater than 1 , we can conclude that $P_{i}$ takes precedence over $P_{j}$ in all cases; if is less than 1 , than $P_{j}$ takes precedence over $P_{i}$ in all cases; finally, if $W_{i j}$ is equal to 1 , than there is a deadlock between the $P_{j}$ and $P_{i}$ in all cases.

In Table 1 below we have synthetized the possible outcomes of the balancing procedure discussed here, and we propose the final outcome characterization from the view points of the individual rights.

In fact, this interpretation is also found in the Romanian literature, two renowned members of our Constitutional Court (Pivniceru and Benke, 2015, p. 57) being those who make such assessments of the result acquired by applying Alexy's formula. By 
Table 1: Possible outcomes of the balancing procedure

\begin{tabular}{cc}
\hline $\mathrm{W}_{\mathrm{ij}}$ values: & The outcome of balancing: \\
\hline $\mathrm{W}_{\mathrm{ij}}>1$ & Excessive \\
$\mathrm{W}_{\mathrm{ij}}=1$ & Stalemate: discretion in balancing \\
$\mathrm{W}_{\mathrm{ij}}<1$ & Proportional \\
\hline
\end{tabular}

Source: Authors' adaptation after Alexy (2014)

performing a comparative examination, the two cited authors concluded that the principle of proportionality is used more and more in proceedings before constitutional courts, although the performance of the test included in this principle is criticized in terms that it does not always involve the comparison of comparable values, recognizing the difficulty in prioritizing certain fundamental rights.

Even considering these difficulties of the proportionality test, starting from the subjective scale of values of each judge, these authors (Pivniceru and Benke, 2015, p. 57) expressed their belief regarding the possibility of overcoming these shortcomings.

Our documentation does not show that supranational jurisdictions, such as those of the European Court of Human Rights, or the Court of Justice of the European Union use Alexy's expressis verbis formula, but following the reasoning of the judges set out in the Court's assessment section, we can see the applicability of Alexy's weighting formula. The proof of this conclusion can be found, at least in Romania, in specialized literature (Papuc, 2019, pp. 165-168) where a transposition of this formula is made by the mentioned author in the case of Wunderlich v. Germany which was pending before the European Court of Human Rights.

\section{Exemplification regarding the applicability of Alexy's formula in assessing the restrictive measures taken in the context of the COVID-19 pandemic}

In order to practically illustrate the applicability of Alexy's formula, we will refer, by way of example, to one of the controversial restrictive measures during the COVID-19 pandemic, namely the suspension of courses and classes with students, respectively the reorganization of teaching activities in online system to limit the risk of Sars-Cov-2 virus infection (public health goal).

This restrictive measure brings into debate the equal and non-discriminatory access to education, with implications, of course, also on the principle of the best interests of the child versus the need to ensure a minimum standard of public health, through precautionary measures such as physical distance, intended to protect children and their families, and prevent community transmission of the virus.

With regard to the 'balancing' of the two competing rights, for the integration of professor Alexy's formula in legal reasoning, we find it useful to conclude the main components of this mathematical model: the importance of the limited right, the intensity of interference with the examined right, and the measure in which this right 
was not fulfilled versus the importance of the realization of the competing principle, and the extent to which the limitation contributes to the realization of this principle-of ensuring public health and safety.

Therefore, we will start by indicating the fact that the right to education, generally, represents an important value that needs to be protected, and, in this regard, for Romania, we can invoke the point of view of an important forum - that of the Romanian Academy (2020) which considers that 'education has profound and lasting implications in all other socio-economic sectors'. Another argument, which we can draw from the case-law of the European Court of Human Rights (Judgment of the European Court in Wunderlich v. Germany case) is that school attendance is beneficial for the prevention of social isolation, contributing to integration into society, and, we would add, to the formation of a wider range of skills than the strictly professional ones.

The above are general conclusions, but also in the opinion of the mentioned forum, when it comes to measures which can affect the right to education, it is imperative to conduct a differentiated examination, depending on the levels of schooling that are correlated with psycho-social needs and cognitive abilities of pupils and students. This way, according to the pedagogy of age groups, it is difficult to implement online education exclusively for pre-school and primary cycles, the same point being expressed, both for the university level, especially for the technical fields or medical specializations for which the training process also implies direct, immediate access to laboratories.

Thereafter, with a view to assessing the impact on the right to education, the socio-economic conditions of the families of the children/students affected by the restrictive measure must also be considered, along with the situation of children or young people with disadvantaged backgrounds who were proved not to have the facilities and infrastructure needed to participate in teaching in this online regime, respectively the children with disabilities, these two categories being those for which the right to education has been affected in its very substance. To substantiate this conclusion, for Romania we consider some statistical data that were mentioned in the Explanatory Memorandum to the draft law that amended the National Education Law (Deputy Chamber of the Romanian Parliament, 2020), data on the risk of poverty or social exclusion among children in Romania and which lead to the conclusion of deepening inequities between children.

Obviously, although we pay special attention to the right to education, we cannot lose sight of the legitimate objective pursued by these measures - public health, that seems to be able to mitigate the weight of its competing right, all the more so as it encompasses the protection of the health of children and their families, the initial view being that the main vector of disease transmission in the community is generally represented by children. But in order to assess the risk of suspending classes in their traditional regime, we should refer to scientific studies that quantify the share of transmission of the virus by children in a community. 
Therefore, currently, we report to some of the studies which show that this share of transmission is quite low (Lee and Raszka, 2020, p. 2), meaning that we find relevant the following conclusions of the quoted research: 'On the basis of these data, SARS-CoV2 transmission in schools may be less important in community transmission than initially feared. This would be another manner by which SARS-CoV2 differs drastically from influenza, for which school-based transmission is well recognized as a significant driver of epidemic disease and forms the basis for most evidence regarding school closures as public health strategy [...]. The researchers provide early reassurance that school-based transmission could be a manageable problem, and school closures may not have to be a foregone conclusion, particularly for elementary school-aged children who appear to be at the lowest risk of infection. Additional support comes from mathematical models, which find that school closures alone may be insufficient to halt epidemic spread and have modest overall impacts compared with broader, community-wide physical distancing measures'.

In terms of the same conclusions, we can also consider the following findings (Posfay-Barbe et al., 2020, p. 3): 'Surprisingly, in 33\% of households, symptomatic HHCs tested negative despite belonging to a familial cluster with confirmed SARS-CoV-2 cases, suggesting an underreporting of cases. In only $8 \%$ of households did a child develop symptoms before any other HHC, which is in line with previous data in which it is shown that children are index cases in $10 \%$ of SARS-CoV-2 familial clusters'.

Nevertheless, we appreciate, that, at this point, the data on this subject are rather contradictory, so a high level of uncertainty remains in these estimates.

In order to summarize the arguments of a legal nature presented above, let us consider the two competing principles, namely P1: The right to education, and P2: Public health assurance. We will apply the weighted formula differentiated into four categories for pre-university students, respectively: preschoolers (E1), primary school students (E2), middle school students (E3), high school students (E4) and two categories of college students, respectively college students from socio-human specializations (S1) and college students from technical specializations (S2). The reason for this separation of categories is the different ways in which the students can participate (or not) in online education techniques.

For our analysis, we have the following variables: $\mathrm{I}_{1 j}$ is the intensity of the interference on the right to education, $\mathrm{W}_{1 j}$ is the importance of the limited right to education, and $\mathrm{R}_{1 j}$ the value of non-realization limited right to education. On the other hand, $\mathrm{I}_{2 j}$ represents the intensity of the interference on the right in favor of which it was regulated, respectively the public health assurance, $\mathrm{W}_{2 j}$ the importance of the right in favor of which the interference was regulated, and $R_{2 j}$ the value of the realization of the right in favor of which the interference was regulated. In the above notations, $j$ is the corresponding category. Also, $\Pi_{1 j}$ and $\Pi_{2 j}$ are the products of the corresponding coefficients for $\mathrm{P} 1$ and $\mathrm{P} 2$, and $\mathrm{W}_{1 j, 2 j}$ the ratios of these products. 
Our assessment procedure proposed here involves four steps:

1. qualitative evaluation using the categorical scale mentioned in the previous section;

2. assigning the corresponding numerical values;

3. calculation of coefficient's products and ratios; and

4. the decision on the balancing outcomes, classified as excessive, stalemate or proportional (as in Table 1).

Table 2 presents the balancing outcomes for the assessment of the restrictive measures to the right to education against the restrictive measures.

The results show us that the restrictive measures were excessive for preschoolers, primary school students and for college students from technical specializations, and were in the margins of the legislator for the other categories.

Table 2: The balancing outcomes for the assessment of the restrictive measures to the right to education

\begin{tabular}{|c|c|c|c|c|c|c|c|c|c|}
\hline \multirow{2}{*}{ Category } & \multicolumn{4}{|c|}{$\mathrm{P} 1$ : The right to education } & \multicolumn{4}{|c|}{ P2: Public health assurance } & \multirow{2}{*}{$\begin{array}{l}\text { Balancing } \\
\text { Outcome }\end{array}$} \\
\hline & $I_{1 j}$ & $W_{1 j}$ & $\mathrm{R}_{1 \mathrm{j}}$ & $\Pi_{1 j}$ & $\mathrm{I}_{2 j}$ & $W_{2 j}$ & $R_{2 j}$ & $\Pi_{2 j}$ & \\
\hline \multirow{2}{*}{ E1 } & $\mathrm{s}$ & s & $\mathrm{R}$ & - & $\mathrm{s}$ & M & $r$ & & Excessive \\
\hline & 4 & 4 & 1 & 16 & 4 & 2 & 1 & 8 & $W_{11,21}=2$ \\
\hline \multirow{2}{*}{ E2 } & $s$ & $s$ & $\mathrm{R}$ & & $s$ & $\mathrm{~m}$ & $r$ & & Excessive \\
\hline & 4 & 4 & 1 & 16 & 4 & 2 & 1 & 8 & $W_{12,22}=2$ \\
\hline \multirow{2}{*}{ E3 } & $s$ & $s$ & $P$ & & $s$ & $\mathrm{~m}$ & $r$ & & Stalemate \\
\hline & 4 & 4 & $1 / 2$ & 8 & 4 & 2 & 1 & 8 & $W_{13,23}=1$ \\
\hline \multirow{2}{*}{ E4 } & $s$ & $s$ & $P$ & & $s$ & $\mathrm{~m}$ & $r$ & & Stalemate \\
\hline & 4 & 4 & $1 / 2$ & 8 & 4 & 2 & 1 & 8 & $W_{14,24}=1$ \\
\hline \multirow{2}{*}{ S1 } & $\mathrm{s}$ & s & $P$ & & $\mathrm{~s}$ & $\mathrm{~m}$ & $r$ & & Stalemate \\
\hline & 4 & 4 & $1 / 2$ & 8 & 4 & 2 & 1 & 8 & $W_{15,25}=1$ \\
\hline \multirow{2}{*}{ S2 } & $s$ & $\mathrm{~s}$ & $\mathrm{R}$ & & $s$ & $\mathrm{~m}$ & $r$ & & Excessive \\
\hline & 4 & 4 & 1 & 16 & 4 & 2 & 1 & 8 & $W_{16,26}=2$ \\
\hline
\end{tabular}

Source: Authors' calculations

The results show us that the restrictive measures were excessive for preschoolers, primary school students and for college students from technical specializations and were in the margins of the legislator for the other categories.

\section{Some limitations of the proposed method}

Our research approach is part of the series of debates and controversies that exist in terms of how reasonable it is to apply the proportionality test when we discuss cases of limitation of human rights (Urbina, 2017, pp. 75-76). The quoted author refers to the assessments of Bernhard Schlink, who argues that 'the balancing of rights, interests and values [...] is unavoidably subjective', and that of Jurgen Habermas who claims that because 'there are no rational standards for bringing values associated 
with constitutional rights into a transitive ordering with other values from case to case $[\ldots]$ weighing takes place either arbitrarily or unreflectively'.

Criticisms about the subjective use of assigned numbers in the implementation of this mathematical model can be overcome, as professor Robert Alexy pointed out (Alexy, 2014, p. 55), if the scale of values is developed through arguments which justify the assignment of those values, as we aimed to do in our case study. Also, some authors have discussed the challenges and the limitations of the proportionality principle (Nishihara, 2012, pp. 7-26; Barak, 2012), especially regarding its effectiveness and adequacy.

The weakness of the proportionality principle is sometimes related to the 'ineffectiveness' to fully guarantee the fundamental rights in some 'emergency' situations, where the government actions can affect individuals in a 'disproportionate' manner. We also believe that some vulnerable points of this formula can be highlighted in the application made by us, given the pandemic context, with all its uncertainties, especially that in assigning the values within this formula it is necessary to stand on reliable statistics.

\section{Conclusions}

Our main conclusion is that the principle of proportionality is a convincing structural approach in the legal reasoning, destined to promote the balance of principles, or as other authors appreciate (Klatt and Meister, 2012, p. 708) 'proportionality and balancing are the most sophisticated means to solve the very complex and intricate collision of human rights with competing principles'.

Such an approach is all the more necessary in the contemporary situation, when we talk about the implementation of artificial intelligence, including in areas such as justice, and develop concepts such as that of predictive justice. Therefore, we believe that an interdisciplinary approach such as the one highlighted in this article is indispensable and will need to be integrated both in the legal discourse of the decision-makers and in the judicial reasoning, in order to contribute, objectively, to sustainable measures that will be socially accepted as well.

In our opinion, some future research might be needed for the proportionality principle to improve its application and for the reported inconveniences to be counteracted. Thus, it is undoubtedly necessary to adopt a unified vision on this principle at the level of supranational jurisdictions, those of the Court of Justice of the European Union, respectively of the European Court of Human Rights.

\section{References:}

1. Alexy, R., 'Constitutional Rights and Proportionality', 2014, Revus. fournal for Constitutional Theory and Philosophy of Law, vol. 22, pp. 51-65.

2. Barak, A., Proportionality - Constitutional Rights and Their Limitations, Cambridge: Cambridge University Press, 2012.

3. Bârsan, C., 'Uniunea Europeană și Convenția Europeană a Drepturilor Omului: Unitate sau Dualitate în Protecția Europeană a Drepturilor Omului' [European Union and European 
Conventions on Human Rights: Unity and Duality in European Protection of Human Rights], 2003, Revista Română de Drept European (Comunitar), vol. 1, [Online] available at www.sintact.ro/, accessed on July 24, 2020.

4. Case of Wunderlich v. Germany, Judgment of the European Court of Human Rights, January 10, 2019, final at 24.06.2019, ECLI:CE:ECHR:2019:0110JUD001892515, [Online] available at http://hudoc.echr.coe.int/eng?i=001-189693, accessed on July 14, 2020.

5. Decision of the Constitutional Court of Romania no. 458 from June 25, 2020 published in the Romanian Official Gazette, Part I, no. 581 from July 2, 2020

6. Decree of the President of Romania no. 195 from March 16, 2020, published in the Official Gazette of Romania, Part I, no. 212 from March 16, 2020.

7. Deputy Chamber of the Romanian Parliament, Explanatory memorandum to the draft law that amended the National Education Law in Romania, [Online] available at www.cdep.ro/ proiecte/2020/100/20/6/exm168.pdf, accessed on July 27, 2020.

8. European Court of Human Rights, 'Explanations Relating to the Charter of Fundamental Rights (2007/C 303/02)', [Online] available at https://eur-lex.europa.eu/legal-content/EN/ TXT/HTML/?uri= CELEX:32007X1214(01)\&from=RO, accessed on July 15, 2020.

9. European Court of Human Rights, 'Thematic Report, Health-related Issues in the Case Law of the European Court of Human Rights', 2015, [Online] available at https://www. echr.coe.int/Documents/Research_report_health.pdf, accessed on July 10, 2020.

10. European Union Agency for Fundamental Rights, 'Coronavirus Pandemic in the EU Fundamental Rights Implications, Bulletin 1', [Online] available at https://fra.europa.eu/ en/publication/2020/covid19-rights-impact-april-1, accessed on July 17, 2020.

11. Klatt, M. and Meister, M., 'Proportionality - A Benefit to Human Rights? Remarks on the I•CON Controversy', 2012, International fournal of Constitutional Law, vol. 10, no. 3, pp. 687-708.

12. Klatt, M. and Meister, M., The Constitutional Structure of Proportionality, Oxford: Oxford University Press, 2012.

13. Klatt, M., 'Proportionality and Justification', in Herlin-Karnell, E. and Klatt, M. (eds.), Constitutionalism Justified: Rainer Forst in Discourse, New York: Oxford University Press, 2019, pp. 159-196

14. Lee, B. and Raszka, W., 'COVID-19 Transmission and Children: The Child is Not to Blame', 2020, Pediatrics, vol. 146, no. 2, e2020004879; DOI: 10.1542/peds.2020-004879.

15. Mazilu-Babel, M., 'Starea de Urgență pentru Prevenirea Răspândirii COVID-19 şi Jurisprudența CEDO Incidentă: Articolele 2, 3, 5, 8, 10, 15 din Convenție' [State of Emergency to Prevent the Spread of COVID-19 and the Incidental ECHR Case Law: articles 2, 3, 5, 8, 10, 15 of the Convention], 2020, Pandectele Române, vol. 1, pp. 153-169.

16. Nishihara, H., 'Challenges to the Proportionality Principle in the Face of 'Precaution State' and the Future of Judicial Review', 2012, Waseda Bulletin of Comparative Law, vol. 30, pp. 7-26.

17. Papuc, T., Principiul Proporționalității. Teorie și Jurisprudența Curții de la Strasbourg [The Principle of Proportionality. Theory and Case Law of the Strasbourg Court], Bucharest: Solomon, 2019.

18. Pivniceru, M.M. and Benke, K., 'Receptarea Principiului Proporționalității în Jurisprudența Curții Constituționale a României. Influențe Constituționale Germane' [Receiving the 
Principle of Proportionality in the Jurisprudence of the Romanian Constitutional Court. German Constitutional Influences], 2015, Revista de Drept Constitutional, vol. 1, pp. 51-71.

19. Poole, T., 'Proportionality in Perspective', LSE Law, Society and Economy Working Papers 16/2010, London School of Economics and Political Science, 2010, [Online] available at http://eprints.lse.ac.uk/32900/1/WPS2010-16_Poole.pdf, accessed on July 10, 2020.

20. Posfay-Barbe, K., Wagner, N., Gauthey, M., Moussaoui, D., Loevy, N., Diana, A. and L'Huillier, A., 'COVID-19 in Children and the Dynamics of Infection in Families', 2020, Pediatrics, vol. 146, no. 2, e20201576, DOI: 10.1542/peds.2020-1576.

21. Romanian Academy, 'Punct de Vedere privind Educația Online' [Opinion on Online Education], July 2020, [Online] available at https://acad.ro/mediaAR/com2020/doc/c0728Punct_de_vedere_Educatia_on-line_si_educatia_in_clasa.pdf, accessed on July 28, 2020.

22. Spielmann, D., 'Allowing the Right Margin: The European Court of Human Rights and the National Margin of Appreciation Doctrine: Waiver or Subsidiarity of European Review?', 2012, Cambridge Yearbook of European Legal Studies, vol. 14, pp. 381-418.

23. Spîrchez, G.B. and Șaramet, O., 'On the Importance of Using the Proportionality Principle in the Analysis of the Limits' Exceedance of the Administration's Discretionary Power', 2018, SUBB Iurisprudentia, vol. 3, pp. 65-90.

24. Urbina, F.J., A Critique of Proportionality and Balancing, Cambridge: Cambridge University Press, 2017. 